\title{
Impact of the Covid-19 Pandemic on Entrepreneurial Capacity and Financial Security in Ukraine
}

\author{
Yana Derbenova ${ }^{1 *}$, Ganna Kashyna ${ }^{2}$, Serhii Leontovych ${ }^{3}$, Olena Ablova ${ }^{4}$, Oksana \\ Dmitrieva $^{5}$, and Lyudmyla Yaremenko ${ }^{6}$ \\ ${ }^{1}$ Taras Taras Shevchenko National University of Kyiv, 01033, str Volodymyrska 64/13, Kyiv, \\ Ukraine \\ ${ }^{2}$ Institute for Military and Strategic Studies of the National Defense University of Ukraine named \\ after Ivan Cherniakhovskyi, 03049, Povitroflotsky Avenue, 28, Kyiv, Ukraine \\ ${ }^{3}$ Center for Military and Strategic Studies of the National Defense University of Ukraine named after \\ Ivan Cherniakhovskyi, Kyiv, Ukraine \\ ${ }^{4}$ WC2R, Great Britain, London \\ ${ }^{5}$ Kyiv National Economic University named after Vadim Hetman, Victory Avenue, 54/1, Kyiv, 03057 \\ Kyiv, Ukraine \\ ${ }^{6}$ Central Ukrainian State Pedagogical University named after Volodymyr Vynnychenko, Departments \\ of Applied Mathematics, Statistics and Economics, 25000, str. Shevshenko 1, Kropyvnytsky, Ukraine
}

\begin{abstract}
The article analyzes the impact of the COVID-19 pandemic on business activities in Ukraine and the world and its financial security. The analysis showed that the economy of Ukraine and most countries of the world suffered significant losses from the introduction of anti-epidemic restrictions on business activity, which turned out to be in the fall of GDP, index of industrial production investment activity. Because of temporary or complete shutdown of business the unemployment rate increased significantly. The pandemic crisis also negatively impacted the financial results of enterprises, which decreased significantly in all kinds of economic activities, especially in industry, transport, temporary accommodation and catering, where the share of unprofitable enterprises reaches $73 \%$. Thus, the problem of ensuring the financial security of business becomes relevant. The aim of the work is to develop methodological approaches to assessing the impact of the pandemic crisis on the financial security of business and to identify effective ways of ensuring such security. In the process of research methods of scientific abstraction, comparative and system analysis and synthesis, systematization and logical generalization were used. It was determined that the pandemic affected small and medium businesses most of all, where a strong negative impact was experienced by more than $60 \%$ of entrepreneurs. Large businesses were less affected, but they also suffered significant losses due to the decline in business activity and demand in the domestic and foreign markets. Agriculture was least affected by the pandemic, which suffered the least losses, primarily due to the insignificant impact of restrictions affecting the activities of this business. The paper systematized the risks arising from the factors of the pandemic crisis,
\end{abstract}

\footnotetext{
*Corresponding author: yanaderbenova@,ukr.net
} 
identifying their manifestations and financial implications for business. As shown by the research, such consequences are manifested in the form of full or partial loss of profits, problems with debt repayment, reduction of financial stability, liquidity, increase in accounts receivable, increased costs for anti-epidemic measures, etc. Thus, the procedure for assessing the business's financial security is to take into account all factors that shape the financial situation of business entities during a pandemic crisis in a comprehensive manner. Keywords: financial security, pandemic crisis, risks, financial stability, security indicators, business financial performance.

\section{Introduction}

An unexpected problem faced by humanity in early 2020 was the COVID-19 pandemic. The pandemic had a significant impact on business activities worldwide and in Ukraine in particular. Especially negative were the consequences of the so-called "lockdown" Lockdown imposed in the spring by most European countries, and Ukraine as well. The complete suspension of work of the majority of trading, service enterprises and transport companies entailed a wave of bankruptcies. Also the unemployment increased and the level of unprofitability of business increased. All of these consequences led to a drop in GDP and decreased revenues to budgets of all levels. The investment processes were curtailed.

The pandemic crisis has become a challenge for most businesses. Therefore, issues of ensuring their financial security have come to the forefront. Financial security is the ability to maintain a positive financial result of the enterprise, the preservation of the value of the enterprise.

\section{Literature review}

In 2020, the COVID-19 pandemic sparked the emergence of scientific research. The studies are related to the impact of this factor on the financial security of the business. In this respect, it is necessary to note the work of N. Fedulova and M. Dzhulai. [1]. The authors use a detailed analysis of the risks faced by businesses in recent years in Ukraine. They offer ways to improve the safety of business from the position of preservation of financial stability.

Also noteworthy is the work of Ivanyuk [2], where he conducts a systematization of factors for the formation of a favourable business environment and business security. The study identifies the main reference points of state support for entrepreneurial activity in the increasing influence of global pandemic challenges.

Strategic priorities of formation of economic security in pandemic conditions at different levels of economic system are considered in their work V. Gorbulin and Y. Danik [3]. This list is far from being complete, with the development of the pandemic there are constantly new publications and research results of the search for effective directions of business security in these conditions.

The purpose of this study is to develop methodological approaches to assessing the impact of the pandemic crisis on the financial security of business and determine effective ways to ensure such security. Due to the crisis situation caused by pandemic COVID - 19, Ukrainian business in 2020 found itself on the verge of survival. Economic recession, reduction in purchasing power and changes in the behavior of citizens, the lack of support (or its ineffectiveness) from the state led to a reduction in production, or even the shutdown of entire sectors of the economy.

\section{Results}


During the crisis, the government introduced a strict regulatory policy, which created barriers to work, reducing the profitability of business. Small and medium-sized businesses were the first to be threatened. Large corporations were also forced to downsize, sending employees on free vacations. Overcoming the consequences of the coronavirus pandemic and quarantine restrictions on the Ukrainian economy is impossible without taking into account the vision and needs of the beneficiaries themselves - business representatives.

The State Statistics Service of Ukraine in 2020 reported that the fall in GDP (percent to the corresponding quarter last year) represented in the first quarter $-1.3 \%$, in the second $11.4 \%$, in the third $-3.5 \%$. At the same time, the largest fall was experienced by such types of economic activity as: temporary accommodation and catering, transport, professional, scientific and technical activities, agriculture, provision of other types of services. The index of industrial production experienced a significant decrease, the dynamics of changes in which is shown in Figure 1.

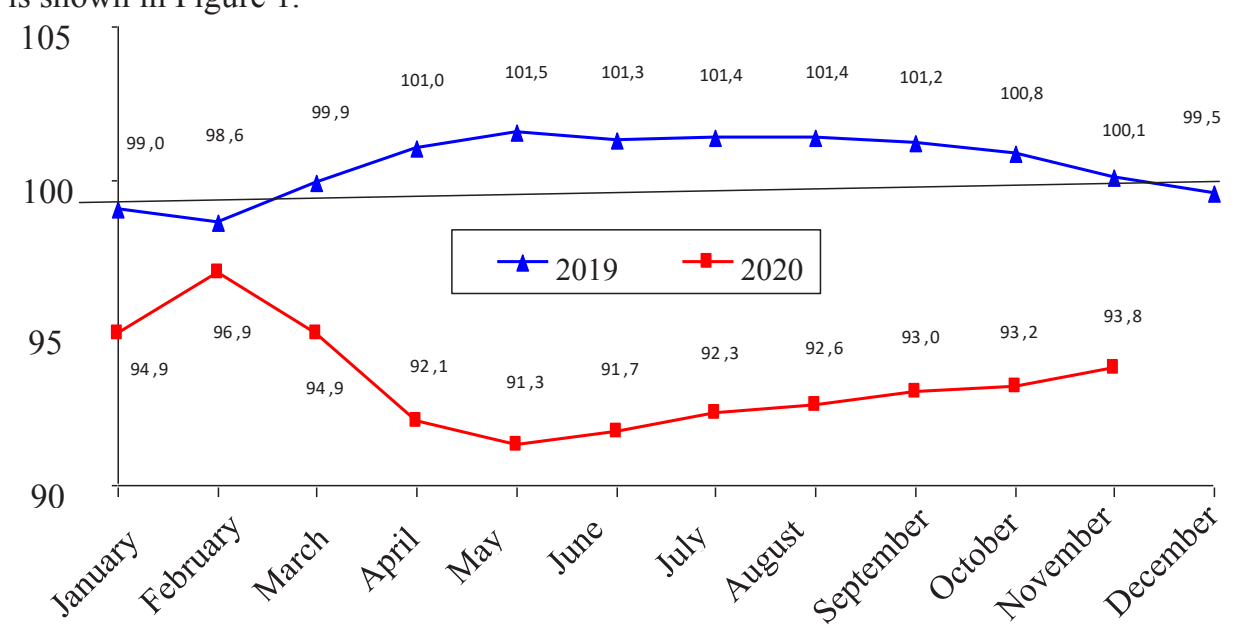

Fig. 1. Indices of industrial production (in $\%$ to the corresponding period of the previous year, cumulative total) [5].

From January to September 2020 the volume of capital investments decreased significantly. As compared with the same period of the previous year they represented $64.6 \%$. The key source of investment remains own funds of enterprises and organizations - $69.2 \%$, which have experienced a significant decrease as a result of the factors of the pandemic crisis.

The introduction of quarantine measures and a decrease in the activity of many entrepreneurial strictures, especially in small business, led to a sharp increase in the level of unemployment in Ukraine. The number of unemployed rose in 2020 from an official 349,000 persons in March to 457,000 in April, 511,000 in May, and 517,000 in June. And only after some mitigation of quarantine restrictions, the number of unemployed decreased to 506 thousand in July and to 474 thousand in August. The slight improvement is partly due to renewed activity of labor migrants.

With the beginning of the pandemic, the Ukrainian financial market was also negatively affected. Figure 2 shows the dynamics of the Ukrainian Equity Index (UX) according to the Ukrainian Exchange [6]. As can be seen from the graph, the UX index experienced a significant drop precisely with the onset of the pandemic crisis in March 2020 and its gradual resumption began only at the end of October. 


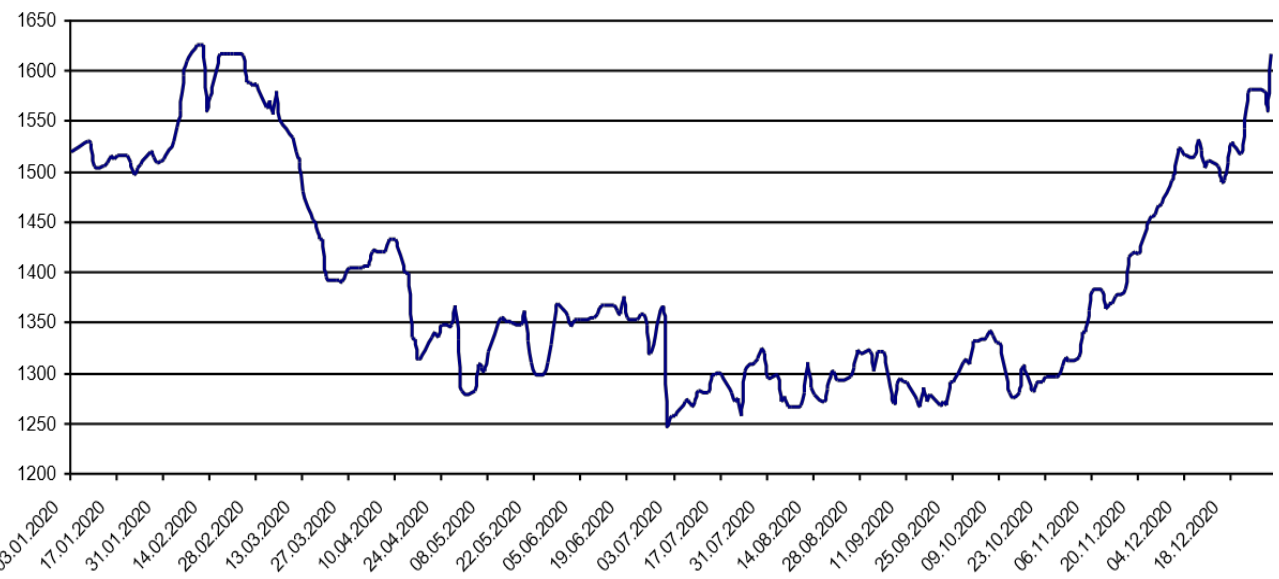

Fig. 2. Dynamics of Ukrainian Equity Index (UX) in 2020 [6]

The negative impact of the pandemic crisis led to a deterioration in the financial results of enterprises in almost all spheres of economic activity (Table 1). This was especially evident in industry, transport, professional scientific and technical activities, art and sports.

Table 1. Financial results of enterprises [5]

\begin{tabular}{|l|c|c|c|c|}
\hline \multirow{2}{*}{$\begin{array}{c}\text { Types of economic } \\
\text { activity }\end{array}$} & \multicolumn{2}{|c|}{ Financial result to taxation } & \multicolumn{2}{c|}{$\begin{array}{c}\text { The number of unprofitable } \\
\text { enterprises in \% of the total } \\
\text { number of enterprises }\end{array}$} \\
\cline { 2 - 5 } & $\begin{array}{c}\text { January- } \\
\text { September } \\
2019, \mathrm{mln} \\
\text { hryvnas }\end{array}$ & $\begin{array}{c}\text { January- } \\
\text { September } \\
2020, \mathrm{mln} \\
\text { hryvnas }\end{array}$ & $\begin{array}{c}\text { January- } \\
\text { September } \\
2019\end{array}$ & $\begin{array}{c}\text { January- } \\
\text { September } \\
2020\end{array}$ \\
\hline Total & 2 & 3 & 4 & 5 \\
\hline $\begin{array}{l}\text { Agriculture, Forestry } \\
\text { and Fisheries }\end{array}$ & 342809,5 & 93318,0 & 22,7 & 34,8 \\
\hline $\begin{array}{l}\text { Industry } \\
\text { Construction }\end{array}$ & 155395,9 & $-44856,9$ & 26,1 & 35,7 \\
\hline $\begin{array}{l}\text { Wholesale and retail } \\
\text { trade; repair of motor } \\
\text { vehicles and } \\
\text { motorcycles }\end{array}$ & 65600,0 & 12512,7 & 16,2 & 27,0 \\
\hline $\begin{array}{l}\text { Transport, } \\
\text { warehousing, postal } \\
\text { and courier activities }\end{array}$ & 8171,9 & $-14888,3$ & 31,4 & 28,1 \\
\hline $\begin{array}{l}\text { Temporary } \\
\text { accommodation and } \\
\text { catering }\end{array}$ & 2603,8 & $-2889,1$ & 18,2 & 73,2 \\
\hline $\begin{array}{l}\text { Information and } \\
\text { telecommunications }\end{array}$ & 16940,9 & 10286,9 & 15,1 & 30,0 \\
\hline
\end{tabular}


Table 1. (continued)

\begin{tabular}{|l|c|c|c|c|}
\hline \multicolumn{1}{|c|}{1} & 2 & 3 & 4 & 5 \\
\hline $\begin{array}{l}\text { Financial and } \\
\text { insurance activities }\end{array}$ & 46268,6 & 165140,7 & 14,3 & 13,6 \\
\hline $\begin{array}{l}\text { Real estate } \\
\text { operations }\end{array}$ & 11020,6 & $-7895,8$ & 29,5 & 57,9 \\
\hline $\begin{array}{l}\text { Professional, } \\
\text { scientific and } \\
\text { technical activities }\end{array}$ & 30005,6 & $-24251,5$ & 29,5 & 34,0 \\
\hline $\begin{array}{l}\text { Administrative and } \\
\text { auxiliary service } \\
\text { activities }\end{array}$ & 2300,5 & 116,1 & 29,9 & 38,5 \\
\hline Education & $-2,7$ & $-67,9$ & 33,3 & 33,3 \\
\hline $\begin{array}{l}\text { Health care and } \\
\text { social assistance }\end{array}$ & 378,6 & 835,9 & 22,6 & 32,6 \\
\hline $\begin{array}{l}\text { Arts, sports, } \\
\text { entertainment and } \\
\text { recreation }\end{array}$ & 416,9 & $-2260,4$ & 40,0 & 63,3 \\
\hline $\begin{array}{l}\text { Provision of other } \\
\text { types of services }\end{array}$ & 113,9 & $-0,5$ & - & 25,0 \\
\hline
\end{tabular}

The pandemic crisis has affected almost all spheres of entrepreneurial activity, especially affecting small and medium businesses. Such sectors as transport, manufacturing, construction, wholesale and retail trade, accommodation and catering services, real estate operations, professional services and other services for the population (e.g. hairdressing services) suffered the most. This is confirmed by a report of the International Trade Center (ITC) entitled "COVID-19 - The big isolation and its impact on small business. The results of a survey conducted by ITC among different companies about the impact they faced through the crisis COVID - 19, is shown in Figure 3.

Similar surveys conducted by INFO SAPINS LLC (limited liability company) for the Representative Office of the Center for International Private Enterprise in Ukraine among Ukrainian small and medium businessmen [8] demonstrated that the main obstacle during the pandemic is the limitation of business activity which together with the reduction of demand at the domestic market and low purchasing power has the most negative effect on business activity. At the same time, economic entities of all sizes are equally affected by this factor: close to $70 \%$ of respondents assessed the impact as "very negative" or "negative". On the whole, quarantine measures, which consist in the introduction of restrictions in the work of businesses led to an overall negative impact on their situation (Fig. 4).

As it can be seen from the diagram, the second most important factor is the continuation of quarantine measures, which has a negative influence on, respectively $69 \%$ of micro-, $65 \%$ of small and $58 \%$ of medium enterprises respectively. Also about half of the respondents indicated difficulties with logistics as a negative factor. One in three small and medium-sized businesses experienced problems through disruption of supply chains and the need to maintain social distance in the communication process. Also influential for exporters was a decrease in demand at international markets. The problems faced by business in connection with the coronavirus pandemic manifested themselves in the emergence of new risks and challenges to which most business structures were not prepared. Especially vulnerable to them were business entities in the sphere of small and medium business, which, according to the results of surveys [8], incurred significant financial losses (Fig. 5). 


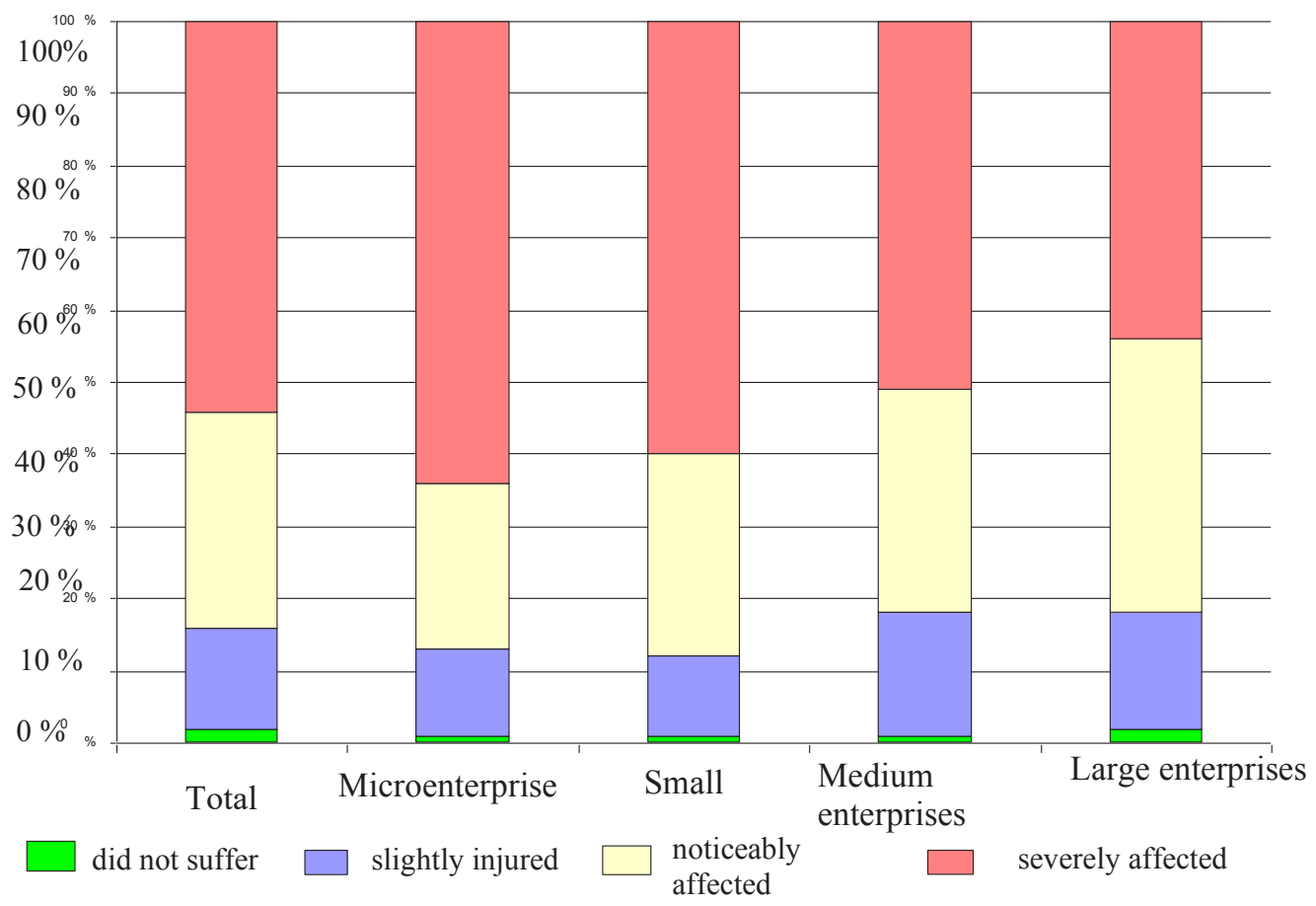

Fig. 3. Impact of the pandemic on the business sphere depending on the scale of the business [7]

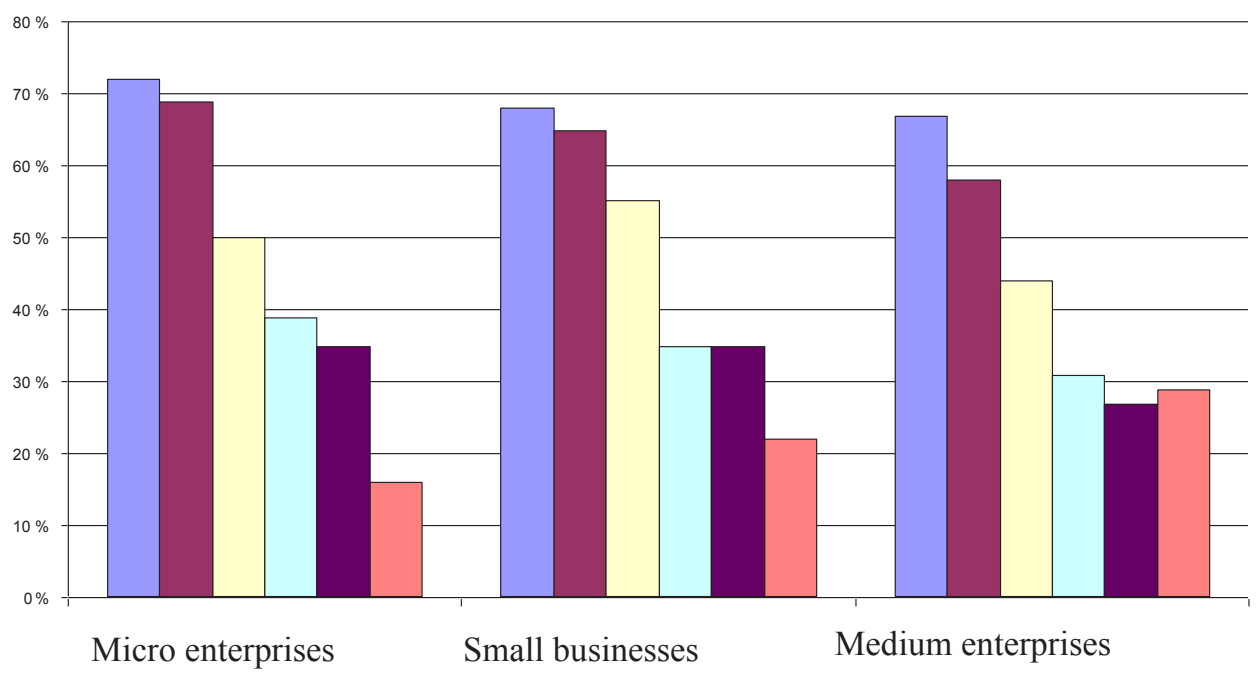

$\square$ Decrease in demand in the domestic market Prolongation of quarantine measures

$\checkmark$ Difficulties with logistics

- The need to ensure social distancing $\square$ Disruption of supply chains

口 Decrease in demand in international markets

Fig.4. Impact of pandemic restrictions on business operations in Ukraine [8] 


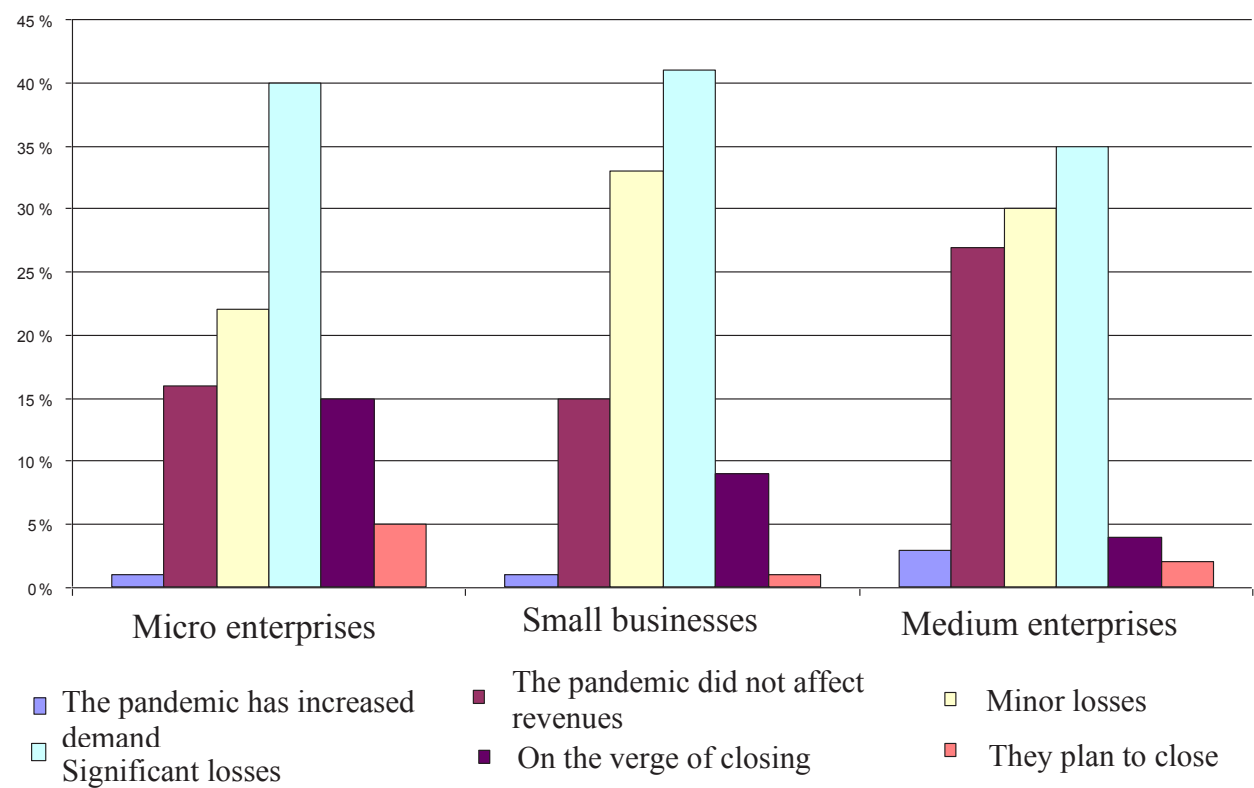

Fig. 5. Business losses from pandemic and quarantine measures [8]

As can be seen from the graph, medium-sized enterprises are the most successful in overcoming the difficulties of the pandemic situation, for $3 \%$ of which demand for products and services has even increased, and for $27 \%$ of whose revenues have not suffered losses from the pandemic.

The analysis (Fig. 6) showed that such sectors as trade, industry, leasing, logistics, transport suffered the most from the pandemic, suffering the greatest losses. Agriculture was least affected by the pandemic, which incurred the least losses, primarily through the insignificant impact of restrictions that affected the activities of this business.

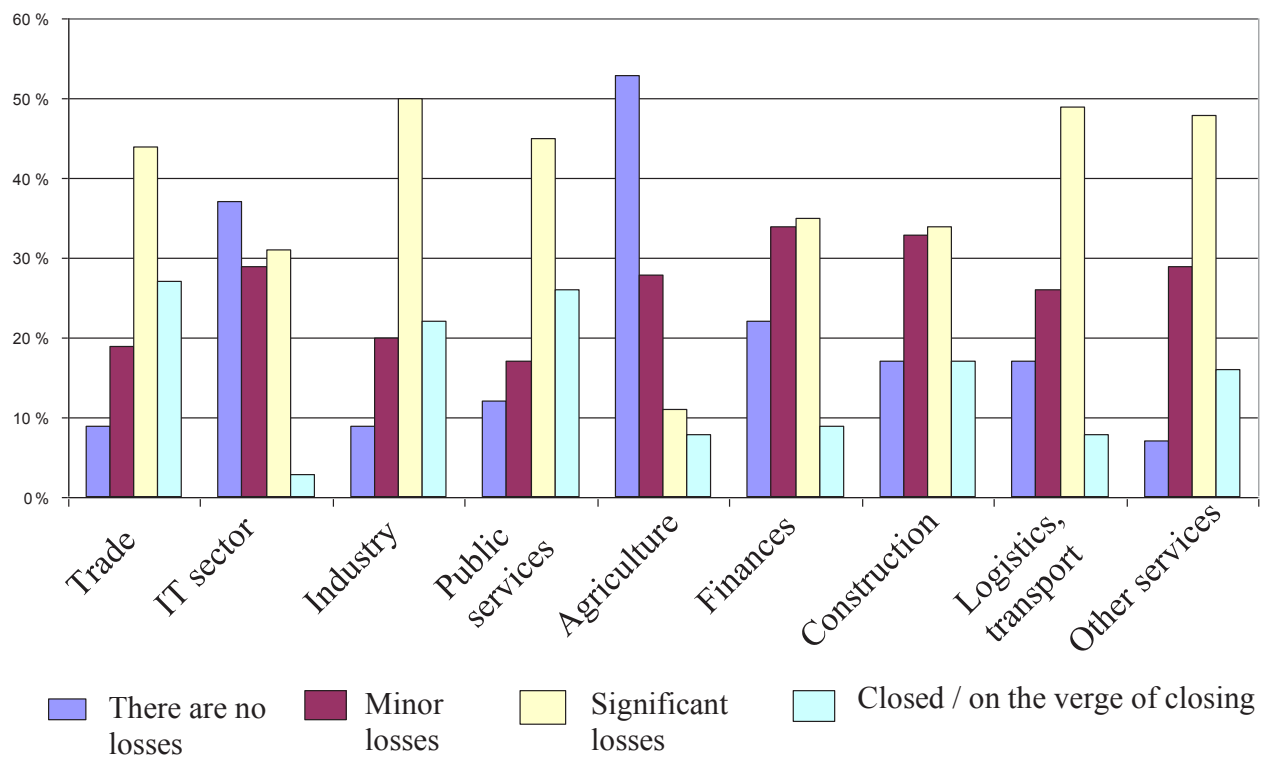

Fig. 6. Pandemic Business Losses by Activity [8] 
Many enterprises have problems with liquidity and solvency, as for more than 2 months there were no sales. Accordingly, there are difficulties with repayment of accounts payable, taxes, salaries, rent, loans and so on. In addition, despite the removal of some restrictive procedures, sales are also weak. In this connection, the state pursues a policy of supporting business by providing, on the one hand, very attractive loans and, on the other hand, by stimulating solvent demand

The results of the research show that the financial security during business pandemic is affected by external (exogenous) and internal (endogenous) risks that arise during the activities of business entities. The action of the corresponding risks leads to a decrease in the financial results and indicators that characterize the financial condition of the enterprise and the level of its financial security. The systematization of such risks is shown in Table 2.

Table 2. Pandemic risks and their financial implications

\begin{tabular}{|c|c|c|}
\hline $\begin{array}{c}\text { Source of } \\
\text { occurrence }\end{array}$ & Manifestation of risk & Financial consequences \\
\hline \multicolumn{3}{|c|}{ Exogenous risks } \\
\hline $\begin{array}{l}\text { Restriction or } \\
\text { complete } \\
\text { prohibition of } \\
\text { activity }\end{array}$ & $\begin{array}{l}\text { Reduction or complete cessation of } \\
\text { production of products or provision of } \\
\text { services. Release of employees. } \\
\text { Interruption of investment and innovation } \\
\text { processes. Loss of sales markets, } \\
\text { connections with suppliers and buyers. } \\
\text { Inability to obtain credit }\end{array}$ & $\begin{array}{l}\text { Partial or complete loss of } \\
\text { profit, reduction of } \\
\text { profitability, financial } \\
\text { stability, liquidity. } \\
\text { Problems with debt } \\
\text { repayment, possibility of } \\
\text { bankruptcy }\end{array}$ \\
\hline $\begin{array}{l}\text { Reduction of } \\
\text { demand on } \\
\text { domestic and } \\
\text { foreign } \\
\text { markets }\end{array}$ & $\begin{array}{l}\text { Decrease in the volume of sales of } \\
\text { products. Reduction of employees. Loss of } \\
\text { markets, connections with suppliers and } \\
\text { buyers. Formation of excessive stocks of } \\
\text { finished goods. }\end{array}$ & $\begin{array}{l}\text { Decrease in revenues and } \\
\text { profits. Deterioration of } \\
\text { profitability indicators. } \\
\text { Increase in expenses for } \\
\text { finished product storage and } \\
\text { marketing activities }\end{array}$ \\
\hline $\begin{array}{l}\text { Restrictions } \\
\text { in transport } \\
\text { operations }\end{array}$ & $\begin{array}{l}\text { Disruptions in the supply of raw materials } \\
\text { and shipment of products. Complications } \\
\text { of logistic processes. Difficulties with the } \\
\text { implementation of foreign economic } \\
\text { operations }\end{array}$ & $\begin{array}{l}\text { Increase in accounts } \\
\text { receivable, increase in } \\
\text { expenses for logistics } \\
\text { activities and delivery of } \\
\text { employees. Decrease in } \\
\text { profits. Decrease of } \\
\text { currency receipts }\end{array}$ \\
\hline \multicolumn{3}{|c|}{ Endogenous risks } \\
\hline $\begin{array}{l}\text { Illness of } \\
\text { workers at } \\
\text { COVID - } 19\end{array}$ & $\begin{array}{l}\text { Loss of human resources potential. } \\
\text { Decrease in labor productivity. The need } \\
\text { to search for staff replacements. }\end{array}$ & $\begin{array}{l}\text { Decrease in revenue and } \\
\text { profits. Sick pay expenses. } \\
\text { Additional expenses for } \\
\text { employee recuperation }\end{array}$ \\
\hline $\begin{array}{l}\text { Necessity to } \\
\text { comply with } \\
\text { anti-epidemic } \\
\text { requirements }\end{array}$ & $\begin{array}{l}\text { Need for protective equipment, medical } \\
\text { equipment (thermometers, disinfectors, } \\
\text { etc.). Implementation of anti-epidemic } \\
\text { measures }\end{array}$ & $\begin{array}{l}\text { Additional expenses for } \\
\text { anti-epidemic measures, } \\
\text { which reduce the total } \\
\text { financial result }\end{array}$ \\
\hline
\end{tabular}


Theory and practice appeals to a huge number of a huge number of indicators to assess financial security, which complicates to some extent the implementation of the analysis, and often gives different results in general. This leads to difficulties in comparing the results of different standards when forming conclusions about financial security. Research shows, that most of the existing methods of financial security analysis contain different, but at the same time somewhat similar methodological principles of such evaluation, the choice of which should take into account the specifics of entrepreneurial activity. Existing criteria of evaluating the level of financial security should be adjusted in order to determine their marginal values. At the same time, it should be borne in mind that quite often one of the peculiarities of entrepreneurial activity is a combination of interests of different categories of recipients of information, since the owner may act both as an investor and a manager.

For the business owner an important characteristic is the return on invested capital in the current period and in the long run. At the same time, the main goal for him is the growth of the value characteristics of the business, which corresponds to the concept of VBM. At the same time managers of the enterprise are mainly interested in factors that affect the performance of current activities, the use of human resources, material and other resources, the development of the business as a whole and the achievement of financial results.

\section{Conclusions}

Thus, it can be noted that in Ukraine as well as all over the world pandemic COVID19 significantly affected the activities of businesses of different forms and sizes. The most painful consequences it had on small and medium-sized businesses, most of which experienced certain restrictions and prohibitions, especially during the lockdown period. Financial results declined significantly in industry, transport, professional, scientific and technical activities, arts and sports. For these and other industries, the problem of ensuring the financial security of business came to the fore. The analysis showed that among the factors of pandemic impact on financial security of business, the most important are risks associated with restriction or complete ban on activities, reduction of demand in domestic and foreign markets, restriction in transport operation, illness of employees on COVID 19. The consequences of the impact of such risks, there is a partial or complete loss of profits, reduced financial stability, an increase in accounts receivable, additional costs for antiepidemic measures, which ultimately reduces the financial security of the business.

\section{References}

1. I. Fedulova, M. Julai, Bulletin of KNTEU, 4, 74-91 (2020).

2. B. Ivanyuk, Financial space, 3 (39), 183-190 (2020)

3. V. Gorbulin, Y. Danyk, Bulletin of the National Academy of Sciences of Ukraine, 5, 318 (2020)

4. The Covid-19 pandemic plunges the world economy into a recession record. Le Monde: Website. URL: https://www.lemonde.fr/economie/article/2020/09/01/lapandemie-de-covid-19-plonge-1-economie-mondialedans-une-recessionrecord_6050618_3234.html

5. Official site of the State Statistics Service of Ukraine URL: http://www.ukrstat.gov.ua

6. Site of the Ukrainian Stock Exchange. URL: http://www.ux.ua/ua/

7. International Trade Center. SME Competitiveness Outlook 2020: COVID-19: The Great Lockdown and its Impact on Small Business. ITC, Geneva. URL: 
https://www.intracen.org/uploadedFiles/intracenorg/Content/Publications/ITCSMECO 2020.pdf

8. Report on the study of micro, small and medium enterprises URL:

https://sapiens.com.ua/publications/socpol-research/135/Info\%20Sapiens

CIPE_report.pdf 